\title{
Early Mesozoic (?Triassic) Landscapes in Australia: Evidence, Argument, and Implications
}

\author{
C. R. Twidale \\ Department of Geology and Geophysics, University of Adelaide, Adelaide 5000, South Australia, Australia \\ (e-mail: rtwidale@geology.adelaide.edu.au)
}

\begin{abstract}
A B S T R A C T
Australia has strong claims to be known as the old continent. In addition to landscapes of later Cretaceous-early Tertiary derivation, remnants of early Mesozoic (Triassic-Jurassic) surfaces, which are part of the contemporary landscape, are also recognized. Being of etch type, they have two ages: one referring to the period of preparation by subsurface weathering and the other to their date of exposure. In many instances, exposure can be dated and the period of preparatory weathering closely inferred. Such old paleosurfaces are demonstrated on Kangaroo Island and are strongly implied in, for example, the Flinders, Gawler, and MacDonnell Ranges; in Arnhem Land and the Arcoona Plateaus; in many parts of the Eastern Uplands; and on several bornhardts in the Yilgarn and Gawler Cratons. They reinforce the suggestion that once in positive relief and shedding water, surfaces persist with little change for long periods. Such ancient features are incompatible with several well-known models of landscape evolution. The chronologies and events they imply extend our understanding of the landscape in the chronological context. They add to our knowledge of Earth's history.
\end{abstract}

\section{Introduction}

Ancient landscapes per se do not feature prominently in most regional stratigraphies. Certainly, they are recorded in unconformities, some of which occasion comment either because of their extent and smoothness, as in the Grand Canyon section (Powell 1875; Sharp 1940), or because of the problems presented by the occurrence of altered bedrock at the geological hiatus (e.g., Van Hise 1896; Weidman 1903; Thwaites 1931; Harper et al. 1995; Sutton and Maynard 1996). Yet very old surfaces are recorded both in the landscape and in the literature. But how old is "old," and of what stratigraphic significance are paleosurfaces?

Erosional land surfaces are of three types: epigene, etch, and exhumed (Twidale 1985). Epigene surfaces are formed by processes active at and near the land surface. A few are due to glacial or eolian scouring. Most epigene surfaces are due to weathering and wash, to the action of running water-primarily to the work of streams and rivers. Most develop a weathered mantle or regolith.

Etch forms (Hassenfratz 1791; Falconer 1911; Jut2000. son 1914; Wayland 1934; Willis 1936) are surfaces that developed as a result of the stripping of the regolith from epigene surfaces and the exposure of the weathering front (Mabbutt 1961). The morphology of etch plains broadly mimics the morphology of related epigene forms (e.g., Hills 1975, p. 300). Etch surfaces are two-stage forms and have two ages (fig. 1): first, the date of subsurface preparation and, second, the period of stripping and exposure (Twidale 1987, 1990).

Epigene and etch surfaces were buried by sedimentary or volcanic deposits and later reexposed as exhumed surfaces. Some exhumed surfaces pose problems in detail. For example, glaciated pavements have long been recognized in stratigraphic section and, where exposed, have been considered resurrected forms. But they are not necessarily exhumed, for they may never previously have been exposed, the glaciers and ice sheets responsible for them having simultaneously bulldozed the preexisting regolith and scoured the weathering front below. They may be etch features.

Nonetheless, the survival of surfaces by burial is largely understood and accepted. Like etch forms, they have two ages: one indicating the date of burial

[The Journal of Geology, 2000, volume 108, p. 537-552] @ 2000 by The University of Chicago. All rights reserved. 0022-1376/2000/10805-0003\$01.00 


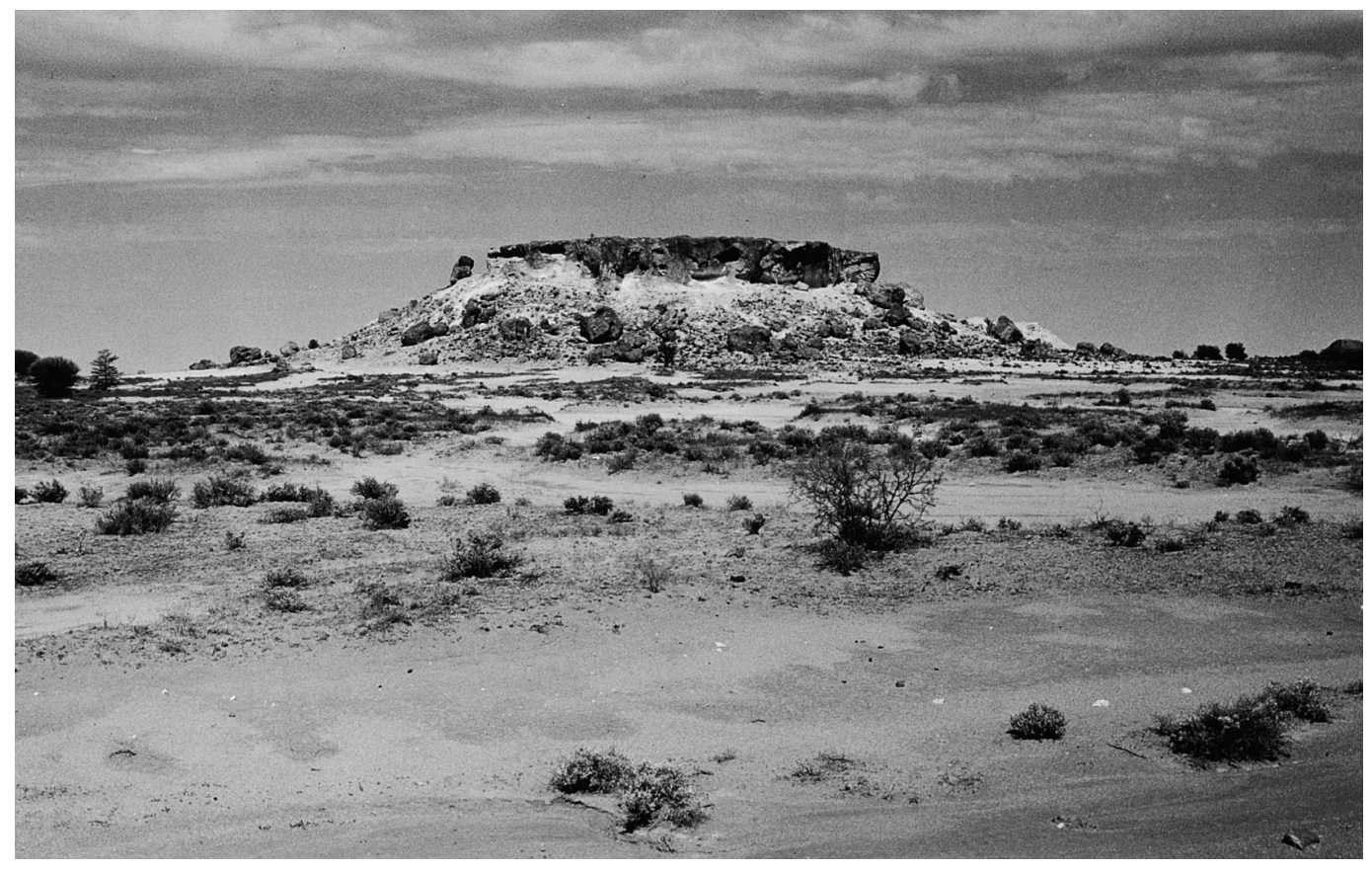

Figure $1 a$

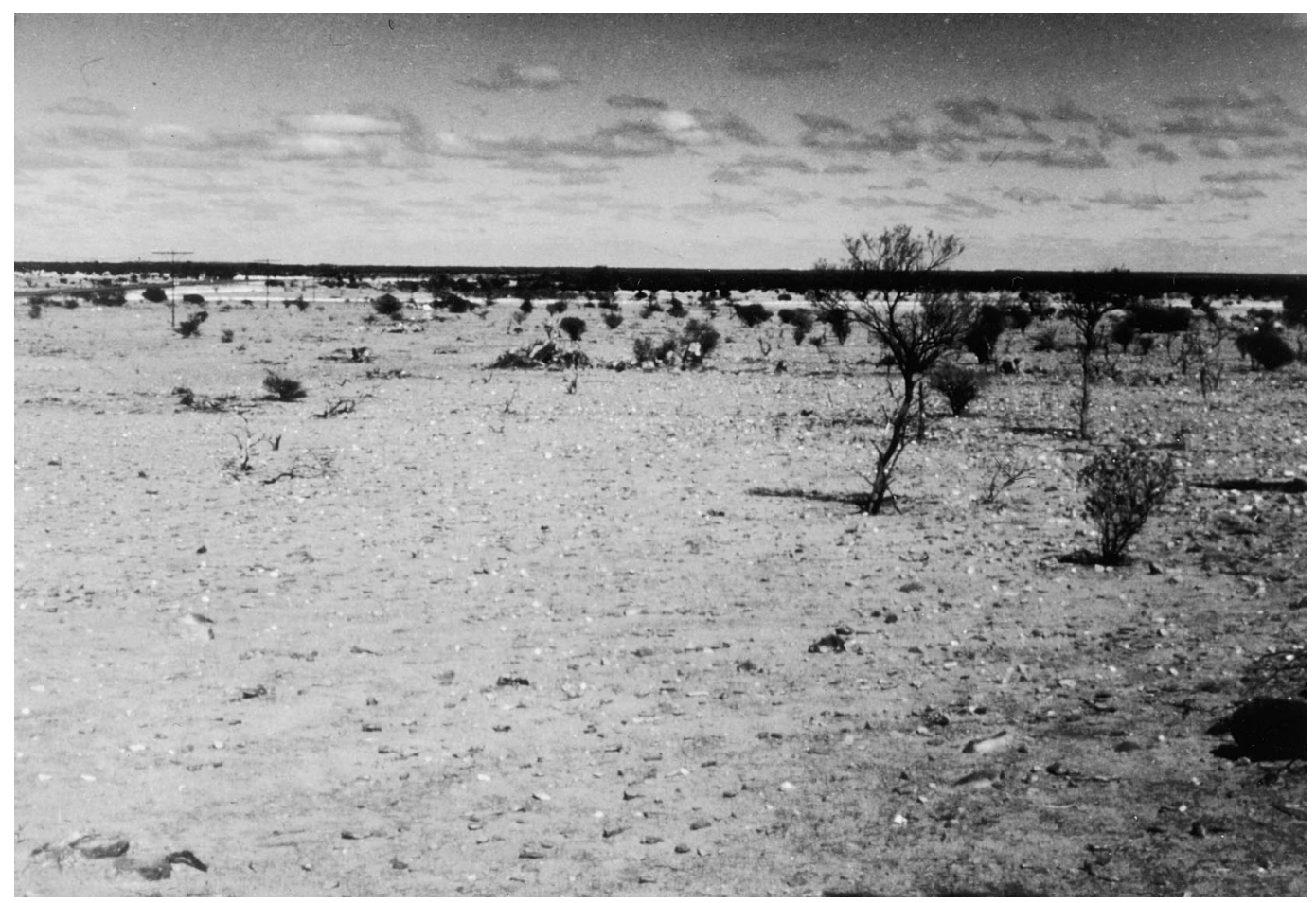

Figure $1 b$

Figure 1. a, This laterite-capped mesa near Cue, in the central part of the Yilgarn Block, Western Australia, is one of many duricrusted remnants in the region, suggesting that formerly (in Cretaceous times) all or most of the region consisted of a weathered planation surface. $b$, Dissection and stripping of the regolith exposed the weathering front as an etch plain of low, virtually nil, relief, part of which is seen here near Meekatharra, also in the central Yilgarn. 
and the other when they were reexposed. They are younger than the youngest rocks they transect and older than the oldest rocks laid down on the surface (fig. 2). In many instances, this hiatus is lengthy (see, e.g., Molina Ballesteros et al. 1995), but in practice the minimum age of origin of the exhumed surface can be taken as immediately predating the oldest cover materials.

Exhumed landscapes ranging in age from Late Archean to Middle Pleistocene have been recognized in Australia where, because of the extent of Cretaceous marine transgressions (Frakes 1988; Reyment 1989|, sub-Cretaceous surfaces are commonplace and extensive. Resurrected surfaces of similar age and type have been recognized from many other parts of the world, including southern Sweden (Lidmar-Bergström 1989) and the famous inselberg landscapes described by Bornhardt (1900) from east Africa (Willis 1936). Exhumed surfaces are an integral component of many old landscapes, which are palimpsest features and comprise elements of different origins and ages (Twidale 1999b).

\section{Possible Ages of Epigene and Etch Land Surfaces}

Landscapes and landforms have conventionally been regarded as youthful and transient. This view finds expression in the classical essays of such early workers as Hutton (1788); in the models of landscape evolution of Davis (1899), King (1942, 1953) and Hack (1960); and in the protests, both formal and informal, that are voiced when unconventional longevity is suggested or discussed (e.g., Bourman 1995). Conclusions vary as to how old landscapes may be (Wooldridge 1951; Thornbury 1954; Linton 1957; Brown 1980), but there is general agreement that most landforms are no older than the Quaternary and that no surface can survive exposure to the elements for more than a few million years or so. Any surface that predates the Tertiary, and in the view of some workers even the later Tertiary, is probably of exhumed type.

Yet there have long been those who have found suggestion and evidence of very old epigene and etch landscapes. Thanks to the extension of regional stratigraphic mapping, to numerical dating of stratigraphic events, and in some measure to a critical revaluation of landscape development models, the last $40 \mathrm{yr}$ or so have seen a gradual appreciation of, first, the extent and distribution of very old (i.e., Mesozoic) surfaces of epigene origin and of, second, the extent and implications of etch surfaces.

\section{The Problem: The Age of Old Paleosurfaces}

Most surfaces of implicit Cretaceous age were first reported from Gondwanan remnants in Australia and Africa (e.g., Hossfeld 1926; Craft 1932; Hills 1934; Dixey 1938; King 1942, 1950). Subsequently, remnants of landscapes of similar antiquity were suggested from the Americas, Asia, and Europe (e.g., Curtis et al. 1958; Demangeot 1978; Poag and Sevon 1989; Briceño and Schubert 1990; Twidale and Vidal Romani 1994; Battiau-Queney 1997).

In addition to these Cretaceous remnants, however, surfaces of even greater imputed age have been recorded. For example, Triassic desert dunes are preserved in unconformity in the Parana Basin of South America (Almeida 1953); some of the escarpments bordering the South Wales Coalfield, such as the minor erosional forms sculpted in granite at Charnwood in the English Midlands (Watts 1903; Bridger 1981), appear to be exhumed sub-Triassic forms; and the entire topographic framework south and southwest of Bristol appears to be of a similar age and origin (Strahan and Cantrill 1904, p. 22; Jones 1931). The summit high plain preserved in central Wales, however, has been interpreted as the epigene equivalent of this exhumed landscape and, though the correlation has not yet been established, Jones's (1931) stratigraphic and topographic analysis is persuasive. In Australia, several of the known later Mesozoic etch surfaces manifestly developed in relation to degradational terrains even older than their etch representatives. How old are these suggested "pre-Cretaceous" remnants?

The purpose of this article is to present evidence and arguments pointing to the early Mesozoic, in some instances putatively Triassic, age of some parts of the contemporary Australian landscape (fig. 3 ) and to consider the possible reasons for, and implications of, their survival.

\section{Earlier Mesozoic Land Surfaces}

Dated Surfaces: The Gulfs Region of South Australia. Three of the four land areas adjacent to Spencer and St. Vincent Gulfs, namely, the Lincoln Uplands of southern Eyre Peninsula, Kangaroo Island, and the Mt. Lofty Ranges (fig. 3), are dominated by lateritized plateaus that are presumed to be remnants of a once contiguous surface. The faulting that produced the regional topography occurred in the Early Eocene, suggesting that the disrupted and weathered high plains and plateaus predate the event and are at least of Paleocene or Cretaceous 


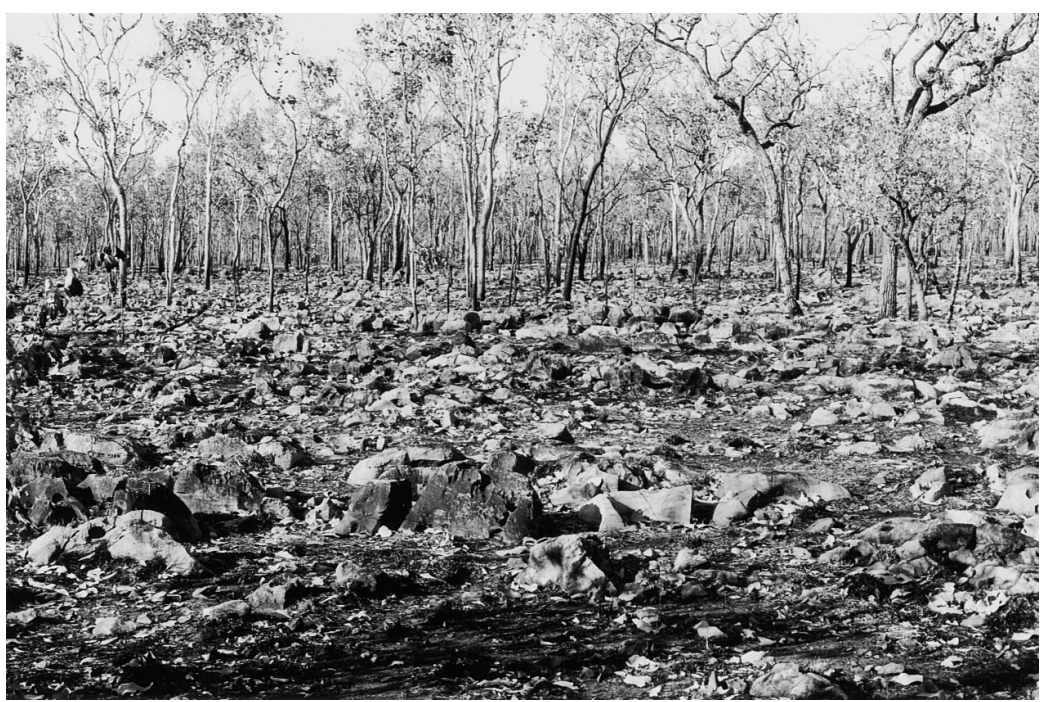

Figure $2 a$

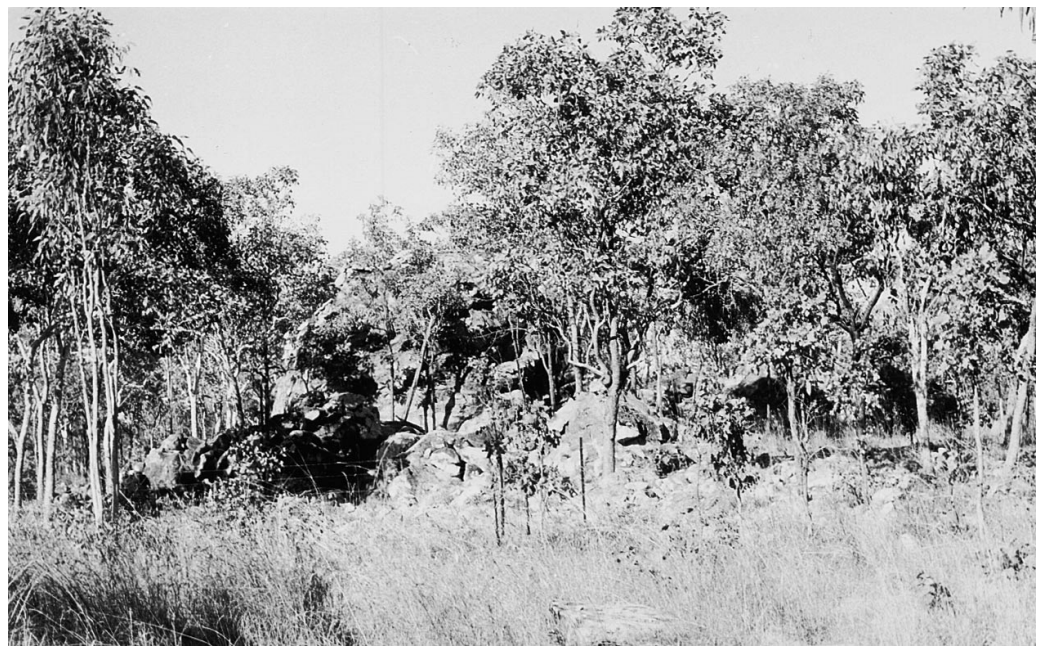

Figure $2 b$

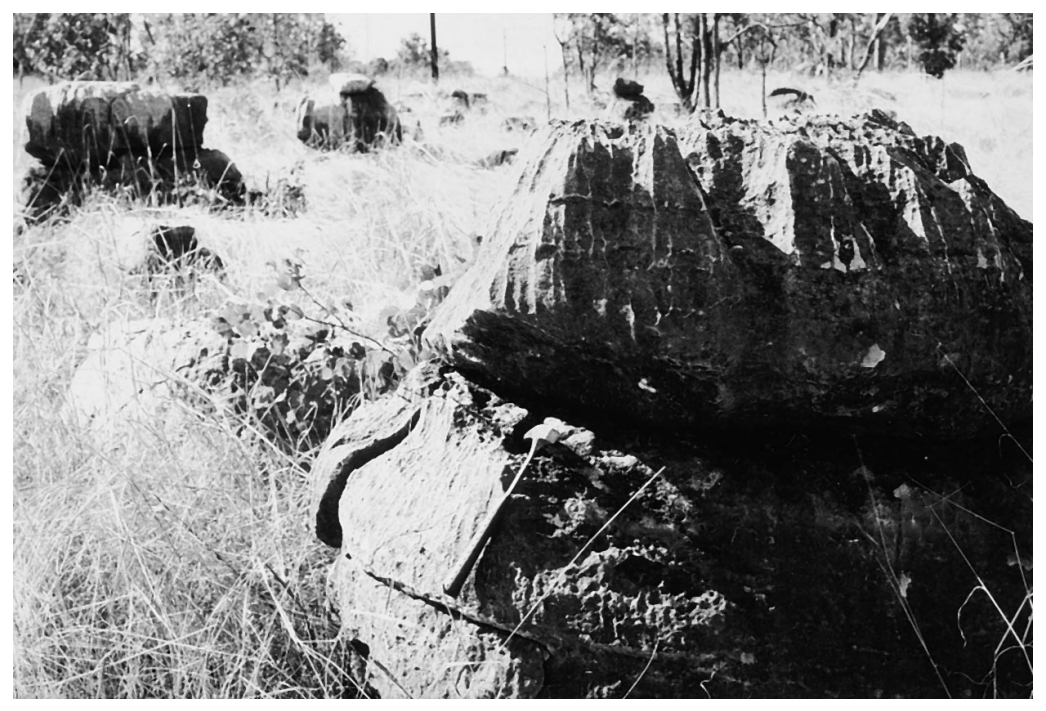

Figure $2 c$ 
age (e.g., Hossfeld 1926; Miles 1952; Campana 1958; Glaessner and Wade 1958).

Evidence from Kangaroo Island, however, suggests a much earlier age for the planation and weathering of the plains before their being faulted, uplifted, and dissected. Like much of what is now southern and central Australia, the Gulfs region was in Early Permian times covered by ice sheets (see, e.g., B.M.R. Palaeogeographic Group 1992) that, along with the associated erosional forms and deposits, constitute an invaluable morphostratigraphic horizon and yardstick for measuring landscape development. Since that time, most landscapes have been shaped by subsurface moisture and running water.

On Kangaroo Island, the laterite capping of the high plain that dominates the topography is developed on Neoproterozoic, Cambrian, and Permian age strata. To the west of Kingscote, the kaolinized horizons of laterite are overlain by a basalt, K-Ar dated at $165 \pm 4,168 \pm 4$, and $175 \pm 4 \mathrm{Ma}$ (Wellman 1971), that is, Middle Jurassic (184-159 Ma) age. West of Penneshaw an apparently similar tholeiitic basalt rests on the ferruginous zone (Tilley 1921). The period of planation, weathering, and lateritization occurred between $295 \mathrm{Ma}$, the Early Permian glaciation, and about $170 \mathrm{Ma}$, when the separation of Antarctica and Australia allowed upwelling of basalt at a divergent plate junction (Daily et al. 1974).

Ferruginous concentration during weathering is reported from cool climates (e.g., Taylor et al. 1992; Young et al. 1994), but lateritic weathering is undoubtedly well developed in hot, humid (monsoon) lands (e.g., Maignien 1966). Such conditions prevailed in what is now southern South Australia throughout much of the Triassic; for this reason the Gulfs region laterite and associated land surface have been tentatively assigned to that period (Daily et al. 1974).

Though disputed for many years (e.g., Schmidt et al. 1976; Bourman 1995), the Mesozoic age of the weathering associated with the surface is corrob- orated not only by the tectonic chronology of the region but also by oxygen isotope analyses (Bird and Chivas 1993). As a result, the possibility of great antiquity for some lateritized surfaces is now conceded by some who earlier opposed such an interpretation (Benbow et al. 1995), though the official and conventional view still finds expression in a slightly earlier map compiled by Cowling and Freeman (1993). On it are depicted areas of "dissected ferruginous duricrusts" - presumably including laterite, for no other formation can be construed as including this material —of earliest Pleistocene age.

Surfaces of Implied and Putative Triassic or TriassicJurassic Age. Gawler Ranges. The Gawler Ranges are a massif developed on Mesoproterozoic ignimbritic dacite and rhyolite. It is bounded on the south by a major fault zone and characterized by a well-developed system of orthogonal or rhomboidal fractures that had been developed during the later Mesoproterozoic. Campbell and Twidale (1991) subdivided the massif into a series of ordered blocks on which bornhardts are developed. Many of these bornhardts display crestal bevels (fig. 4). Together they can be construed as remnants of the Nott Surface, which is highest in the south and declines to the north. It can be traced into unconformity in the Eromanga Basin, where the Mt. Anna Sandstone member of the Cadna-owie Formation is formed of detritus from the erosion of the regolith formed on the Gawler Ranges massif during Early Cretaceous (Neocomian-Aptian) times (Wopfner 1969). Thus the stripping of the regolith from the uplifted massif and the exposure of the weathering front as an etch surface comprising beveled bornhardts took place in the Early Cretaceous; however, prior planation and weathering are clearly implied (fig. 5).

The degradation of what has been termed the Beck Surface occurred in the Jurassic and possibly the Triassic (Campbell and Twidale 1991), but it cannot be older because the region was inundated by Permian ice sheets. The disruption of the Beck Surface was caused by the upfaulting of the south-

Figure 2. $a$, This karst plain eroded in flat-lying Cambrian limestone is near Tindal, in the north of the Northern Territory, Australia. In Early Cretaceous times, it was inundated by a shallow epicontinental sea and by an associated arenaceous sequence. It has been exhumed as a result of the extensive erosion of the Cretaceous sequence, remnants of which are preserved in scattered low hills, providing evidence of the age and character of the karst plain. $b$, In all instances the unconformity is coincident with the level of the adjacent plain. $c$, Numerous pinnacles and small towers of limestone stand on the limestone plain. The presence of sandstone in joint clefts (hammerhead) and smears of iron-indurated sandstone on the limestone surfaces suggest that these minor karst forms also predate the Cretaceous transgression and have been exhumed (see Twidale 1984). 


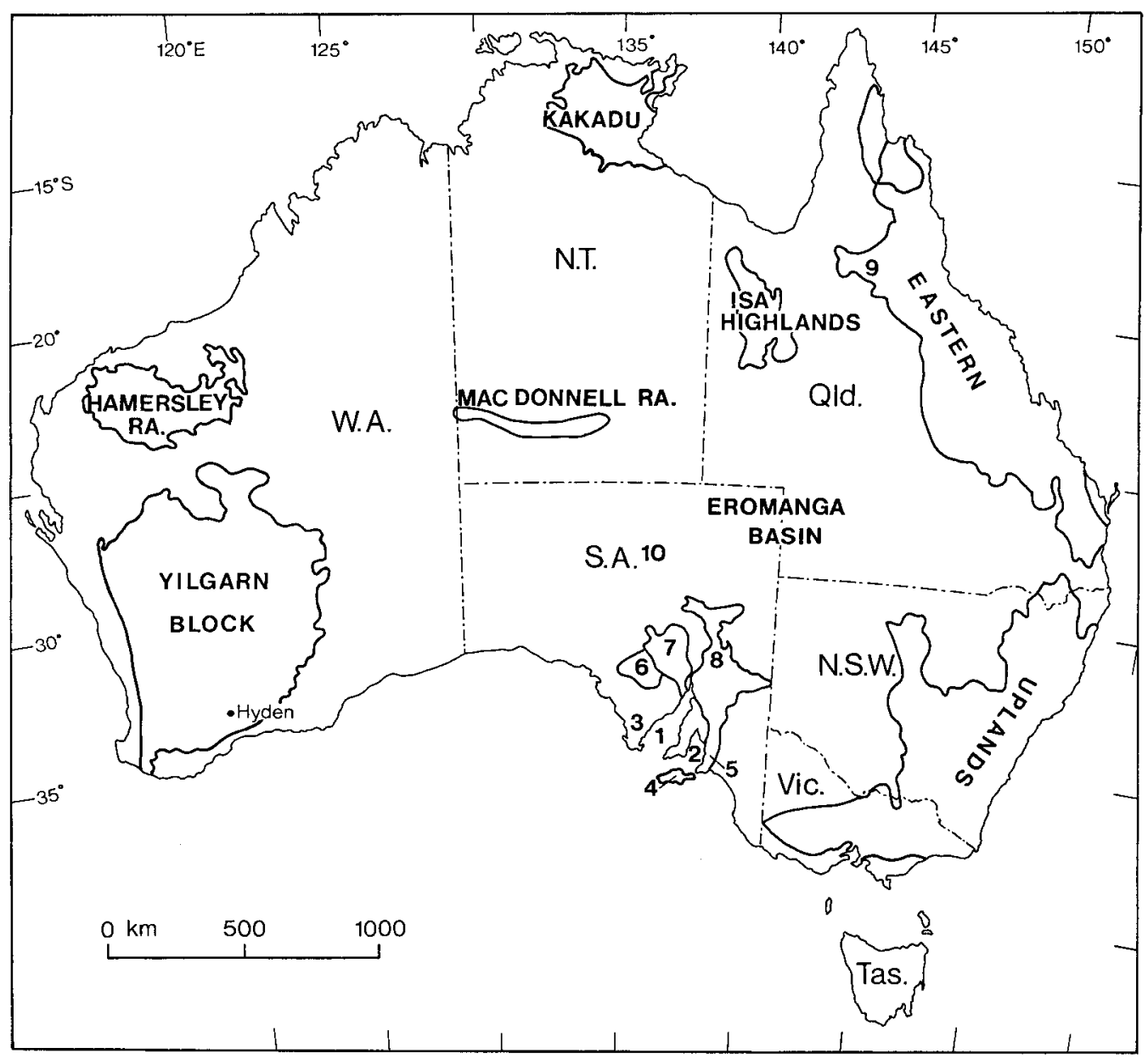

Figure 3. Location map showing Australian places, regions, and features mentioned in the text. Several locations are numbered: Spencer Gulf (1), Gulf St. Vincent (2), Lincoln Uplands (3), Kangaroo Island (4), Mt. Lofty Ranges (5), Gawler Ranges (6), Arcoona Plateau (7), Flinders Ranges (8), Einasleigh Uplands (9), Peake and Denison Ranges (10).

ern margin of the ignimbritic massif, possibly related to the separation of Australia from Antarctica. As far as is known, no remnant of the Beck Surface survives, since the regolith was stripped except for a few scattered patches preserved on valley-side slopes (e.g., just east of Nonning Homestead and near the Thurlga-Paney-Yardea track junction), and none of the isolated residuals (such as Mt. Nott) that stand above the general level of the etch surface is beveled. Nevertheless, the former existence of a low-relief planation surface predating the Early Cretaceous but younger than the Permian is clearly predicated by the present landscape of the Gawler Ranges massif.

The presence of Eocene silcrete (Firman 1983) in the western piedmont of the Gawler Ranges shows that the massif was upstanding throughout most of the Cenozoic. Only thin and localized sequences of Cenozoic strata from the upland occur in adjacent basins and valleys such as the Corrobinnie Depression, south of the Gawler Ranges (e.g., Binks and Hooper 1984).

The implied early Mesozoic planation and weathering that produced the Beck Surface lends credence to the suggestion (Twidale and Bourne 1975) that the etch surfaces preserved on the higher inselbergs on northern Eyre Peninsula also originated by subsurface weathering in the earlier Mesozoic.

Arcoona Plateau. The Arcoona Plateau lies in the arid interior of South Australia and west of Lake Torrens, from which it is separated by a major fault zone in the Torrens Lineament. It is developed on a sequence of Neoproterozoic quartzite, sandstone, and shale that dips very gently north. A succession of thin but resistant arenaceous strata forms cap- 


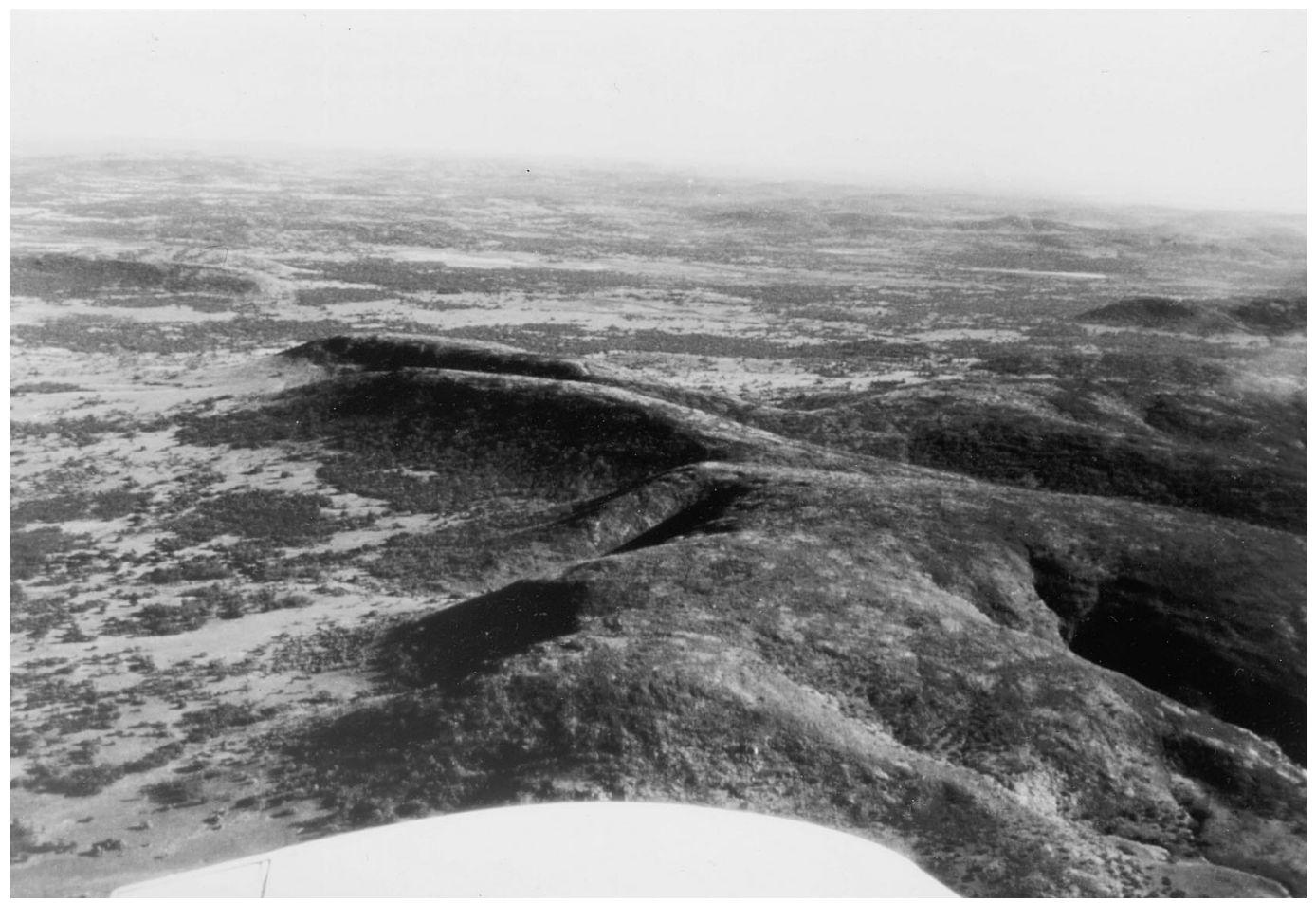

Figure 4. Part of the Nott Surface, a dissected Early Cretaceous etch plain preserved as a summit bevel in the Gawler Ranges, South Australia. (Courtesy E. M. Campbell.)

rocks and plateaus. The presence of Eocene strata at the base of the Torrens Lineament scarp suggests a Cretaceous age for the Arcoona Plateau, but as in the Gulfs region, this is too young a date. During the Early Cretaceous, shallow epicontinental seas invaded the region, and associated marine strata remain in several of the valleys incised below the general plateau level. These strata demonstrate that the planation surface that now forms plateau remnants predates the Early Cretaceous, as does its dissection. Again, however, the area was glaciated during the Permian, and a Jurassic-Triassic age for the landscape represented by the plateau remnants is indicated.

The paleosurface is readily traced southward into the Tent Hills, west and southwest of Port Augusta, where the Arcoona Plateau is preserved on the Neoproterozoic Simmens Quartzite. It occurs also to the west in the Baxter Range, where a rolling high plain is developed on essentially undeformed Neoproterozoic quartzite, and in Baxter Hills, where a high plain is preserved on a Neoproterozoic sequence of folded and faulted strata that includes quartzites. Silcrete of presumed Miocene age (e.g., Twidale and Bourne 1996) is developed and pre- served in the dissected scarp-foot, piedmont zones, and valley floors.

Flinders Ranges. The Flinders Ranges are a ridge and valley region developed on folded Neoproterozoic and Cambrian strata, with several Triassic outliers preserved in the central and southern sectors. The prominent planation surface transecting folded sediments, as well as igneous rocks preserved in the northern Flinders Ranges, is of exhumed type and sub-Cretaceous age (Woodard 1955). It is, however, confined to that part of the upland (Twidale and Bourne 1996). The ridge and valley topography of the southern Flinders Ranges predates the Eocene (Twidale and Bourne 1996), and the bevels preserved in ridge crests throughout the upland (fig. 6) are, except for the exhumed northern extremity, of Cretaceous age and epigene type.

Upward-fining of strata is reported from the Triassic Springfield Basin of the southern Flinders Ranges. It has been attributed to a reduction in relief amplitude in the surrounding terrain during deposition (Johnson 1961). The fossil flora and fauna also imply a low-relief catchment. Similar evidence of quiet water, paludal conditions, and sluggish drainage are found in the nearby Bool- 


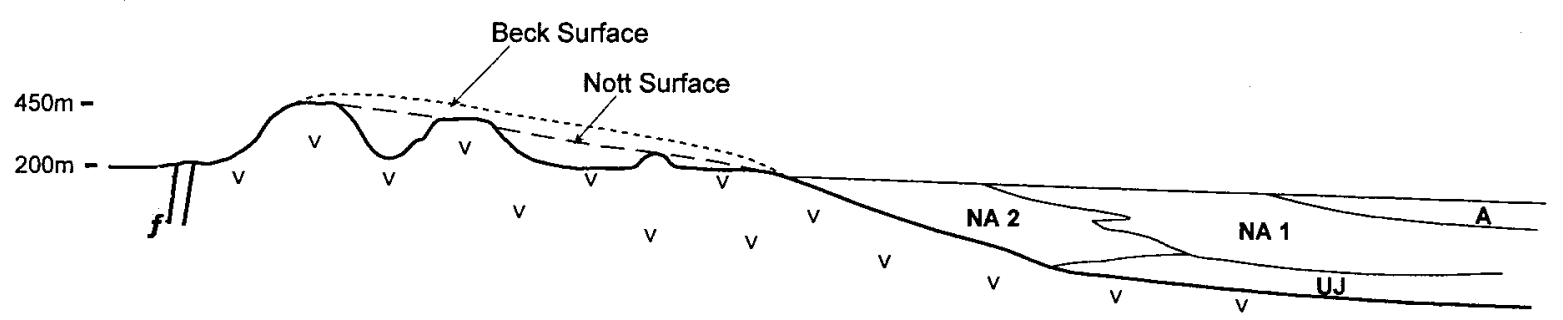

Figure 5. Diagrammatic section through the Gawler Ranges and adjacent sector of the Eromanga Basin. Upper Jurassic Algebuckina Sandstone (UT); Neocomian-Aptian Cadna-owie Formation (NA1); Mt. Anna Sandstone member (NA2); Aptian Bulldog Shale (A). (In part after Wopfner 1969, p. 152.)

cunda Basin and in the Triassic brown coal basins of the Leigh Creek and Copley areas (e.g., Parkin 1953; Wopfner 1969; Kwitco 1995).

Although pre-Cretaceous planation surfaces of sub-Cretaceous and putative Cretaceous ages have been recognized in the upland, none of Triassic date has yet been demonstrated, despite the sedimentological evidence of their previous existence: they may persist but have not yet been identified. The summit high plain of the Flinders Ranges is exhumed and of sub-Cretaceous age in the north, but throughout, most of the upland is epigene or etch in origin. Here it predates the Eocene but may be multicyclic, and partly Cretaceous, partly older, in age.

Peake and Denison Ranges (Also Known as the Denison and Davenport Ranges). This minor horst upland is an isolated extension of the Flinders Ranges structure and involves Proterozoic strata as well as granitic rocks. A remarkably smooth summit bevel, the Mt. Margaret Plateau, cuts across the structure. It has a complex chronology, appearing to be a composite of exhumed sub-Cretaceous and Pleistocene gypsite surfaces (Wopfner 1968). It is devoid of any substantial regolith, is of etch type, and must have been initiated prior to the transgression of the Early Cretaceous epicontinental seas.

MacDonnell Ranges. The MacDonnell Ranges and associated fold mountain belts of central Australia trend latitudinally and involve Proterozoic and early and middle Paleozoic strata. The ridge and valley topography is dominated by quartzitic ranges, many of which are distinctly beveled. Many, standing some $10-30 \mathrm{~m}$ above the valley floors, can be correlated with duricrusted remnants of Miocene age (Mabbutt 1966; Woodburne 1967).
On the crests of the highest ranges, however, are other bevels of etch type. Some stand adjacent to the lower planate surfaces and, like them, are developed on quartzite. They are older and may be related to the Cretaceous seas that extended over the plains both north and south of the uplands. According to Mabbutt (cited in Brown et al. 1968, p. 304), however, they could have developed "prior to the Cretaceous." These two interpretations can be accommodated by suggesting planation and weathering before the transgression of the (Early) Cretaceous seas, followed by dissection and stripping of the regolith either by wave action or, more probably, by rivers and streams graded to the Cretaceous shorelines. If this interpretation is correct, the summit surface of the MacDonnell Ranges is comparable in origin and age to that preserved in the Gawler Ranges, also located near the Early Cretaceous shoreline, approximately $800 \mathrm{~km}$ to the south.

Einasleigh Uplands and Isa Highlands, North Queensland. The Eastern Uplands of Australia developed on a complex of orogens that includes cratonic elements in the far north. Differential weathering and erosion produced fold mountains in Paleozoic strata, as well as typical granite terrains where batholiths are exposed, but summit high plains are prominent everywhere in the upland. Basaltic volcanicity related to several hot spots throughout the Cenozoic permitted the dating of valleys and associated land surfaces (many of which predate the Eocene), as well as the estimation of erosion rates, which are extraordinarily slow (e.g., Taylor et al. 1985; Young and McDougall 1993). Very old land surfaces of later Mesozoic age are preserved throughout the uplands (e.g., Baragwanath 1925; Craft 1932; Hills 1934; Twidale 1956; 
De Keyser 1964; Young 1977, 1983; Bishop 1988; Hill 1999).

In the Einasleigh Uplands of north Queensland, the exhumed character and minimum age of the summit surface of the Gregory and Newcastle Ranges are demonstrated by the remnants of cover sediments (Twidale 1956). They are members of the Jurassic age freshwater Gilbert River Formation (Smart et al. 1971). They occur as far east as the Newcastle Range, where the erosional bevels transect rocks that include Permian felsite (Twidale 1956; Branch 1966), but are not found farther to the east, where the prominent planation surface preserved in a summit high plain (see De Keyser 1964) may be epigene, fluvial, and graded to the later Mesozoic shoreline.

The prominent sub-Jurassic summit surface of the Einasleigh Uplands can be traced in unconformity into the Carpentaria Basin and to the west in the Isa Highlands, on the northeastern margin of the Australian Craton (Twidale 1956; Carter and Öpik 1959a). Remnants of a Mesozoic cover, the Polland Waterhole Shale (the sandstone facies of which contains plant remains indicating a Late Jurassic age; Carter and Öpik 1959a, 1959b), are preserved at various altitudes on the smooth but domed surface eroded in the folded Proterozoic strata and intrusives. The planation surface on which these sediments were deposited clearly predates the Late Jurassic, but by how much is not known.

Arnhem Land (Kakadu). The Arnhem Land massif is a dissected plateau developed in an essentially flat-lying Mesoproterozoic arenaceous sequence. Extensive areas stand 200-250 m above sea level. Although in detail irregular, and scored by many deep gorges and with innumerable fracturecontrolled clefts or slots, the plateau surface can be construed as being the remnant of a weathering front developed beneath the former high plain. The massif itself already existed in Early Cretaceous times-a shoreline of that age has been recognized at the base of the prominent scarp on the western flank of the upland; Cretaceous strata extend up valleys; and on the eastern side of the upland an Early Cretaceous shoreline has been recognized at an elevation of approximately $75 \mathrm{~m}$ (Skwarko 1966; Needham 1982; Frakes and Bolton 1984).

Thus, what is now the Arnhem Land massif predates the Early Cretaceous. It is not known how many (etch) surfaces are fragmentarily preserved in the dissected high plain, but clearly they are at least of earliest Cretaceous age and are probably older.

Bornhardts in the Southern Yilgarn Block, Western Australia. Several of the granitic inselbergs of the southern Yilgarn Block or Craton can be dated in relation to the lateritic surface, of which substantial but scattered remnants remain. The laterite surface (the Old Plateau of Jutson 1914) was dated in relation to the widespread dated valley fills that gave an Eocene age for the incision of rivers and the initiation of the New Plateau (Commander 1989; Clarke 1994). Thus the lateritic Old Plateau is at least of Cretaceous age.

Many inselbergs of the region have been exposed as a result of the erosion of the lateritized duricrust (Twidale and Bourne 1998). They are younger than the laterite and are of Eocene and younger ages, depending on the distance from drainage lines. Some inselbergs, however, stand higher than, and are presumably at least as old as, the Old Plateau. Some, like the Humps near Hyden, rise several scores of meters higher than the adjacent laterite surface. They are stepped, and the Humps' prominent flared bluffs, which mark former piedmont zones, stand about $60 \mathrm{~m}$ higher than the surrounding plains (fig. 7; cf. Twidale and Bourne 1975; Twidale 1982). However, the steps are interpreted as related either to inclined or essentially horizontal piedmont plains; several phases of weathering and erosion are implied, and the higher sectors of this and other morphologically similar features could predate the Cretaceous.

\section{Discussion}

Survival. The evidence for very old etch surfaces in the contemporary Australian landscape is not conclusive everywhere but is highly suggestive. Paleogeographic maps (B.M.R. Palaeogeographic Group 1992, p. 55-70) show that throughout the earlier Mesozoic, and especially throughout the Triassic and most of the Jurassic, much of what is now the Australian landmass was exposed to weathering and erosion. Planation surfaces dating from this extended time period can be expected. The field evidence suggests that they were well developed and that substantial remnants of them remain.

The survival of very old paleoforms is favored by several aspects of the long-term Australian environment, including remoteness from plate boundaries; comparative tectonic stability; low latitude mitigating against glaciation and nival effects during the later Cenozoic; and, as a consequence of this, the preservation of old regoliths. It is germane to ask how some land surfaces have persisted despite long-term exposure to the elements. Several possible survival factors and mechanisms have been suggested (e.g., Twidale 1976, 1991): 


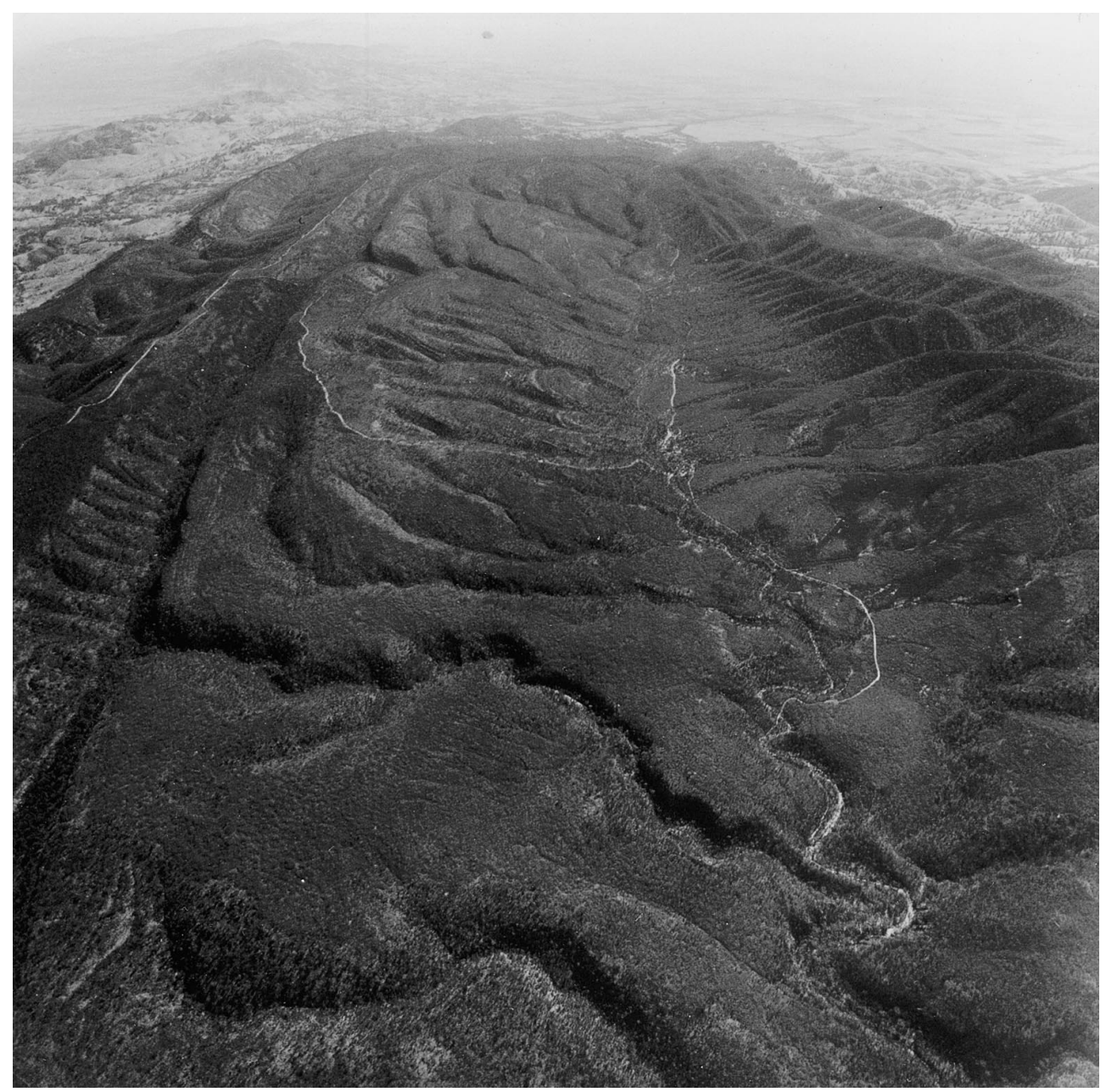

Figure 6. A summit bevel transecting Proterozoic sandstones involved in a plunging syncline in the Battery Range, southern Flinders Ranges, South Australia. The surface is of probable Cretaceous age. (Courtesy Department of Environment and Natural Resources, South Australia.)

1. Some strata are inherently resistant to prevailing systems of weathering and erosion. In some instances, this is due to their composition, but more frequently, resistance is due to fracture density and condition (tight or open), and this varies with the local and regional stress regime. Any factor that reduces contact with moisture (such as massive structure) is conservative, for water is the most potent weathering and erosive agent on Earth. Arising in part from such structural considerations, protection against contact with moisture is a preservative factor at regional, local, and site scales (Twidale and Bourne 2000a).

2. Australia is not and never has been tectonically stable in absolute terms, though vast areas have not been subjected to orogenesis or major earth movements for hundreds of millions of years; even in the more active eastern orogenic belts, the most recent mountain building occurred at approximately $250 \mathrm{Ma}$. Regions like the Kimberley Block, the Arnhem Land massif, the Arcoona Plateau, and the Forster Range (near Barrow Creek, Northern Territory) are underlain by Proterozoic sequences that remain essentially undisturbed 600-1000 m.yr. after they were laid down. There has been ample time during periods of crustal quiescence for weathering and planation. Nevertheless, minor earth movements as evidenced by neotectonic faulting and folding are widely observable in the landscape (e.g., Wopfner 1960; Sprigg 1963; Gordon and Lewis 1980; Twidale and Bourne $2000 b$ ). Such crustal movements, together with the many drops in sea level throughout time, would cause widespread stream rejuvenation, stripping of 


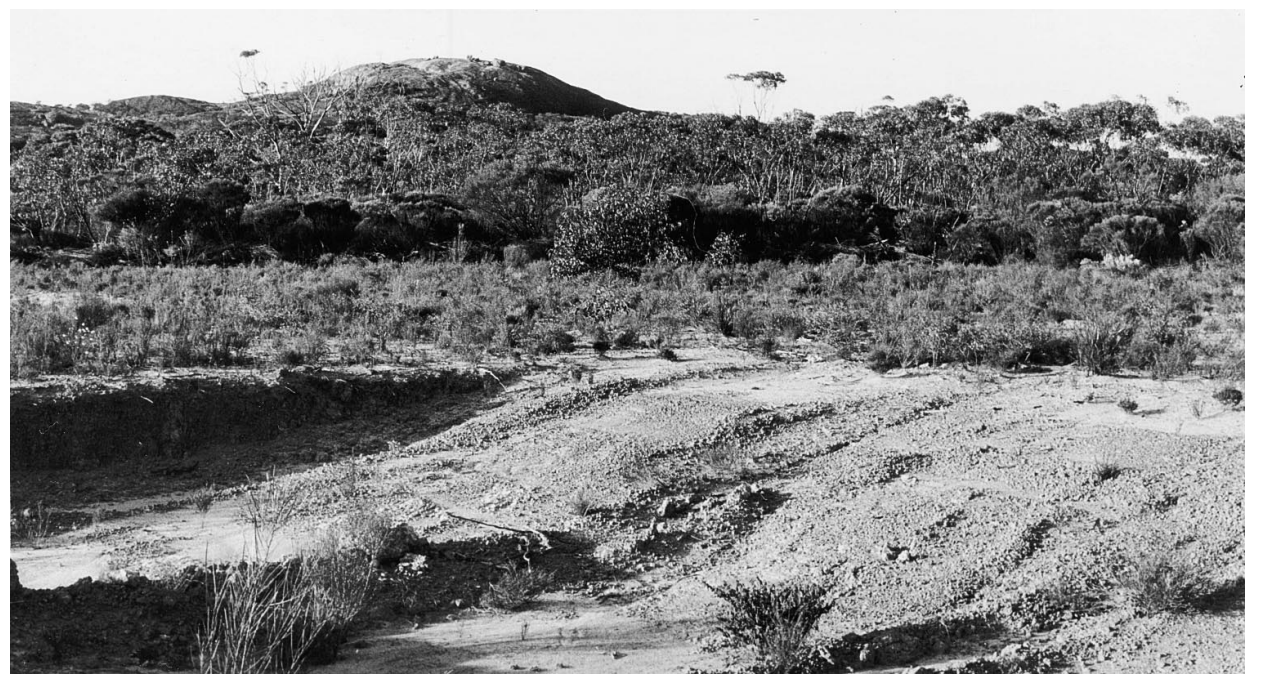

Figure $7 a$

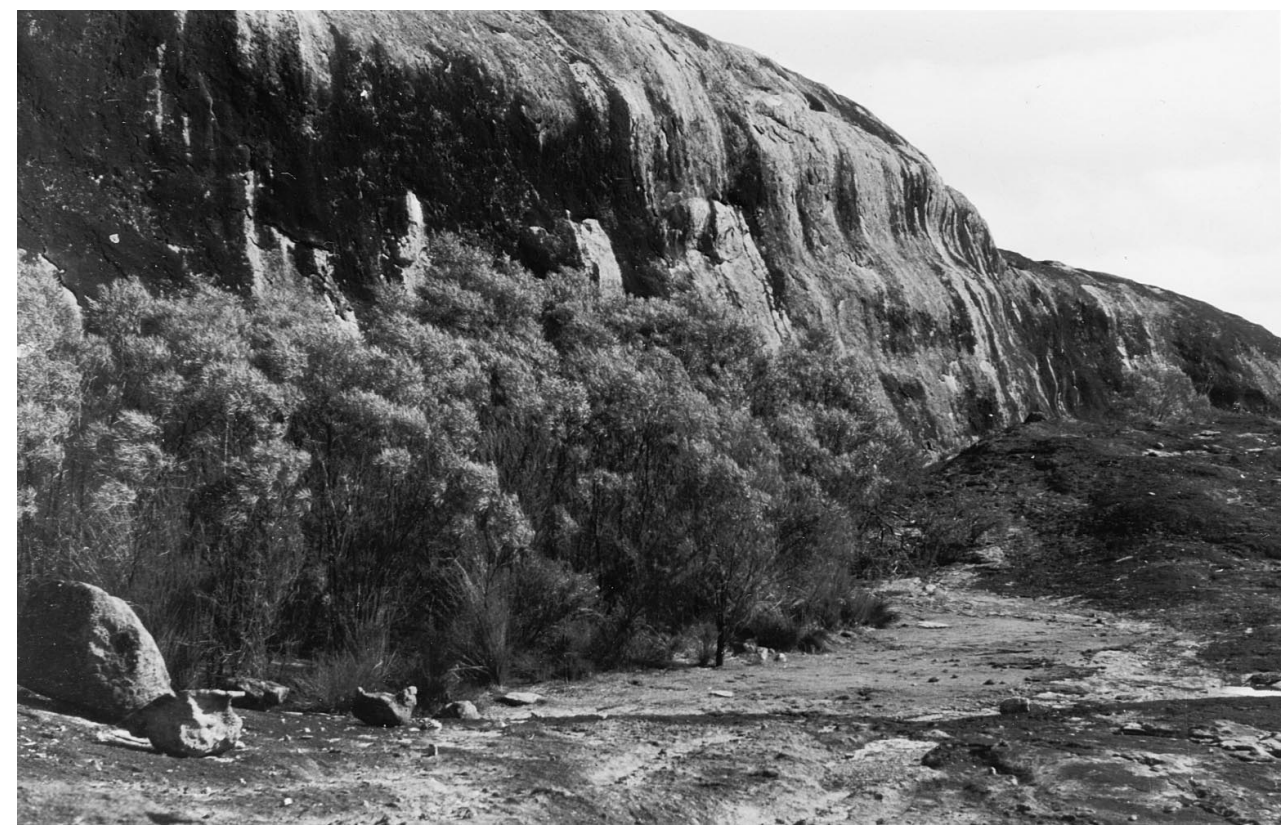

Figure $7 b$

Figure 7. $a$, The Humps is a complex bornhardt in granite gneiss located near Hyden in the southern Yilgarn Block of Western Australia. It stands higher than the surrounding lateritized Cretaceous plain, and high on the residual is a flared wall $(b)$, indicative of a former hill-plain junction.

susceptible regoliths (Twidale 1999a), and exposure of etch surfaces with bedrock exposed.

3 . Weathering and erosion are not uniformly active over the continental areas. Apart from climatically based inequalities in the rates at which these processes act (e.g., Corbel 1959; Judson and Ritter 1964), field evidence suggests that although major rivers and streams effectively erode their beds and banks, interfluves may be degraded much more slowly: they are "out of reach of erosion" (Knopf 1924, p. 637) or in zones of nil erosion (Knopf 1924; Crickmay 1932, 1976; Horton 1945). Degradational processes may not be evenly distributed over the land surface in all conditions (cf. Davis 1909, p. 267).

4. The effects of such unequal activity tend to be enhanced and perpetuated as a result of the operation of reinforcement or positive feedback mech- 
anisms. All rivers tend to be self-perpetuating, because once the river is incised, for whatever reason, not only runoff but also subsurface seepage gravitates to the channel, which thus incises deeper and captures more and more of the local drainage. In a similar fashion, once in positive relief, a bornhardt tends not only to survive because it sheds water but also to grow as a relief feature because of the lowering of the adjacent plains that are weathered and eroded by the excess runoff.

Stratigraphic Implications. The very old paleosurfaces from various parts of Australia evidence significant events in Earth's history. At the western margins of the Eromanga Basin, some of the adjacent land areas were, in later Mesozoic times, covered by the seas (e.g., Jack 1931; Frakes 1988). During these marine transgressions, as evidenced in the Gawler, MacDonnell, and Flinders Ranges, adjacent land areas were stripped of the weathered mantles accumulated during prolonged earlier periods of weathering and erosion, by rivers flowing to the Cretaceous shorelines.

Appreciation of the etch origin of such surfaces assists in the understanding of features displayed in associated sedimentary deposits. Thus, the Gawler Ranges massif has been upstanding throughout the Cenozoic. It is an etch surface from which the regolith was stripped during the Early Cretaceous. The exposed dacitic and rhyolitic rocks are resistant to weathering, and consequently, little detritus has been delivered to adjacent basins and valleys since that event.

Judging from the few surviving remnants in Jurassic and earliest Cretaceous times, the weathered mantle of the Gawler Range Volcanics consisted of corestones (or core-boulders) set in a grussy matrix of sand and clay. This was the source for the Neocomian-Aptian Mt. Anna Sandstone. Corestones are typical of regoliths derived from impermeable but pervious rocks, and they are due to differential subsurface weathering of the corners and edges of joint blocks. The moisture that affects most of the alteration descends into the bedrock from the surface. Hence, the nearer the surface, the longer the duration of weathering. For this reason, and all else being equal, weathering is most advanced close to the land surface. The resultant corestones are smallest and most altered close to the land surface rather than at depth, where meteoric waters penetrated later. Such weathering patterns explain why the distribution of boulders of volcanic material in the Mt. Anna Sandstone is the reverse of that produced by weathering in situ: the smallest and most rotted corestones occur lower in the sequence be- cause the upper horizons of the regolith were the earliest eroded, transported, and deposited.

Again, the lateritized land surface of the Gulfs region was the source for detritus delivered to various basins after the rifting of the southern margin of Australia in the later Cretaceous and earliest Tertiary. Much of the sediment was delivered to the depositional basins as kaolinitic clay from the lateritic profiles and is not the result of subsequent weathering. On the other hand, the Banded Iron Formations of the Hamersley Ranges evidently did not lend themselves to kaolinization (though King 1989 , p. 96, reports a "lateritic" profile from the flanks of Mt. Bruce), and the pisolitic regolith produced by weathering during the Cretaceous was translocated and biogeochemically reconstituted as the commercially exploited Robe River Pisolite following relative uplift (recession of the Cretaceous seas?) during the Eocene (Twidale et al. 1985).

In a somewhat different context, the crests of the higher and older inselbergs of the Yilgarn Block are, like other old landscape remnants, refuges in which ancient plant species survive. Thus, while erosional sectors of continents are not now depicted on geological or other maps as blank spaces decorated by metaphorical dragons or elephants, they are nevertheless mental blanks to many, and at best are simply labeled "land" or "islands in the X seas." Yet they could in many instances be shown as, for example, weathered planation surfaces or etch plains, the character of which can possibly be related to the strata of adjacent depocentres, but which in any case constitute a part of Earth chronology.

Implications for Models of Landscape Evolution. Such very old landscapes confirm what has tacitly been accepted for many years, namely, that in a tectonically undisturbed landscape, weathering and erosion work from the surface downward so that the lower a degradation surface stands in a landscape, the younger it is (see Rütimeyer 1769; Baulig 1952, p. 171; Twidale 1956). The position of exhumed unconformities vis-à-vis epigene and other types of land surface is determined by tectonics, but epigene and etch surfaces occur in ascending order of age in the landscape.

Favorable though conditions may have been for the conservation of land surfaces, the imputed persistence of such features from the Triassic and earlier Jurassic virtually doubles the earlier estimated and increasingly accepted duration of survival. Such possible features of this antiquity, if real, pose enormous problems, and it is not surprising that many remain incredulous. On the other hand, as 
several writers have remarked (e.g., Namier 1955, p. 5), not all that is irrational is unreasonable.

The suggested long-term survival of land surfaces runs contrary to Huttonian concepts of continual change (Hutton 1788) and to ideas concerning baseleveling (Powell 1875) and extreme planation (the "universal ultimate denudation" of Crickmay 1974, p. 172). Very old epigene and etch paleosurfaces are incompatible with conventional theories of landscape evolution such as those of Davis (1899), King (1942), and Hack (1960). Despite published expressions of disbelief and incredulity, the notion that landforms can persist through the ages, and by implication, that long-continued weathering and erosion does not necessarily result in complete baseleveling or the eradication of all signs of earlier surfaces and forms, has gained a measure of acceptance during the past 2 decades (e.g., Twidale 1976, 1994; Young 1983; Bishop 1988), giving rise to a model of landscape development that accommodates such ancient landscapes (Twidale 1991).

\section{Conclusion}

In Australia, the preservation of paleosurfaces has been, and remains, favored by a concatenation of circumstances (Twidale 1999b). The Island Continent is not unique in this regard, for older Mesozoic surfaces are reported from other parts of the world. But Australia has been comparatively stable for the past $250 \mathrm{~m}$.yr. or so, and over much of the continent for approximately 600-1000 m.yr. There has been time for weathering and planation during periods of relative stability and enough local and regional baselevel changes to induce stripping of regoliths and etch planation. Thus, in Australia the landscape records events commonly extending back to the beginning of the Mesozoic and, in some instances and areas, even longer.

Such geomorphological data and interpretations fill what are otherwise lacunae in Earth history. The approximately $250 \mathrm{~m}$.yr. between the withdrawal of the Permian glaciers, on the one hand, and the rifting and separation of what became Australia and the advance of the later Mesozoic seas, on the other, was not a void, either mental or real. The contemporary land surface may, as King (1989, p. 3) has suggested, be an accident of geology and time, but it has a story to tell, and some of that relates to the earliest years of the sequence of events during which the Earth's surface has attained its present arrangement and configuration.

\section{R E F E R E N C E S C I T E D}

Almeida, F. F. M. 1953. Botucatú, a Triassic desert of South America. Int. Geol. Congr., 19th (Algiers, 1952) 7:9-24.

Baragwanath, W. 1925. The Aberfeldy district, Gippsland. Mem. Geol. Surv. Vic. 15, 45 p.

Battiau-Queney, Y. 1997. Preservation of old palaeosurfaces in glaciated areas: examples from the French western Alps. In Widdowson, M., ed. Palaeosurfaces: recognition, reconstruction and palaeoenvironmental interpretation. Lond. Geol. Soc. Spec. Publ. 120: 125-132.

Baulig, H. 1952. Surfaces d'aplanissement. Ann. Geogr. 61:161-183, 245-262.

Benbow, M. C.; Callen, R. A.; Bourman, R. P.; and Alley, N. F. 1995. Deep weathering, ferricrete and silcrete. In Drexel, J. F., and Preiss, W. V., eds. The geology of South Australia. Vol. 2. The Phanerozoic. Geol. Surv. S. Aust. Bull. 54:201-207.

Binks, P. J., and Hooper, G. J. 1984. Uranium in Tertiary palaeochannels "West Coast area," South Australia. Proc. Autralas. Inst. Min. Metal. 289:271-275.

Bird, M. J., and Chivas, A. R. 1993. Geomorphic and palaeoclimatic implications of an oxygen-isotope chronology for Australian deeply weathered profiles. Aust. J. Earth Sci. 40:345-358.

Bishop, P. 1988. The eastern highlands of Australia. Prog. Phys. Geogr. 12:159-182.
B.M.R. (Bureau of Mineral Resources) Palaeogeographic Group. 1992. Australia: evolution of a continent. Canberra, Aust. Gov. Publ. Serv., 96 p.

Bornhardt, W. 1900. Zur Oberflachengestaltung und Geologie Deutsch Ostafrikas. Berlin, Reimer, 595 p.

Bourman, R. P. 1995. A review of laterite studies in southern Australia. Trans. R. Soc. S. Aust. 119:1-28.

Branch, C. D. 1966. Volcanic cauldrons, ring complexes, and associated granites of Georgetown Inlier, Queensland. Bur. Miner. Resour. Geol. Geophys. Bull. 76, 158 p.

Briceño, H. O., and Schubert, C. 1990. Geomorphology of the Gran Sabana, Guyana Shield, southeastern Venezuela. Geomorphology 3:125-141.

Bridger, J. F. D. 1981. The glaciation of Charnwood Forest, Leicestershire and its geomorphological significance. In Neale, J., and Flenley, J., eds. The Quaternary in Britain. Oxford, Pergamon, p. 68-81.

Brown, D. A.; Campbell, K. S. W.; and Crook, K. A. W. 1968. The geological evolution of Australia and New Zealand. Oxford, Pergamon, 409 p.

Brown, E. H. 1980. Historical geomorphology: principles and practice. Z. Geomorph. Suppl. 36:9-15.

Campana, B. 1958. The Mt. Lofty-Olary region and Kangaroo Island. In Glaessner, M. F., and Parkin, L. W., eds. The geology of South Australia. Melbourne, Melbourne University Press, p. 3-27. 
Campbell, E. M., and Twidale, C. R. 1991. The evolution of bornhardts in silicic volcanic rocks in the Gawler Ranges. Aust. J. Earth Sci. 38:79-93.

Carter, E. K., and Öpik, A. A. 1959a. Geological map of Northwestern Queensland. Canberra, Bur. Miner. Resour. Geol. Geophys., scale 1 inch : 10 miles.

- 1959b. Urandangi. 4-mile geological series. Sheet F/54-5, Australian National Grid. Bur. Miner. Resour. Geol. Geophys. Expl. Notes 1, 16 p.

Clarke, J. D. A. 1994. Geomorphology of the Kambalda region, Western Australia. Aust. J. Earth Sci. 41: 229-239.

Commander, D. P., comp. 1989. Hydrogeological map of Western Australia. Perth, Geol. Surv. W. Aust., scale $1: 2,500,000$.

Corbel, J. 1959. Vitesse d'érosion. Z. Geomorph. 1:1-28.

Cowling, W. M., and Freeman, P. J., comps. 1993. Geological map, South Australia. Geol. Surv. S. Aust., Dept. Mines Energy, Adelaide, scale $1: 2,000,000$. In Drexel, J. F., and Preiss, W. V., eds. The geology of South Australia. Vol. 2. The Phanerozoic. Geol. Surv. S. Aust. Bull. 54 (pocket inside back cover).

Craft, F. A. 1932. The physiography of the Shoalhaven Valley. Proc. Linn. Soc. N. S. W. 57:245-260.

Crickmay, C. H. 1932. The significance of the physiography of the Cypress Hills. Can. Field Nat. 46: $185-186$.

- 1974 . The work of the river. London, Macmillan, $271 \mathrm{p}$.

- 1976. The hypothesis of unequal activity. In Melhorn, W. N., and Flemal, R. C., eds. Theories of landform development. Binghamton, State University of New York, p. 103-109.

Curtis, G. H.; Evernden, J. F.; and Lipson, J. 1958. Age determination of some granitic rocks in California by the potassium-argon method. Calif. Div. Mines Spec. Rep. 54, 16 p.

Daily, B.; Twidale, C. R.; and Milnes, A. R.; 1974. The age of the lateritized summit surface on Kangaroo Island and adjacent areas of South Australia. J. Geol. Soc. Aust. 21:387-392.

Davis, W. M. 1899. The geographical cycle. Geogr. J. 14: 481-504.

- 1909. The geographical cycle. In Johnson, D. W., ed. Geographical essays. Boston, Dover, p. 249-278.

De Keyser, F. 1964. Innisfail, Queensland. $1: 250,000$ geological series. Bur. Miner. Resour. Geol. Geophys. Expl. Notes, 30 p.

Demangeot, J. 1978. Les reliefs cuirassés de 1'Inde du Sud. Trav. Doc. Geogr. Trop. 33:97-111.

Dixey, F. 1938. Some observations on the physiographical development of central and southern Africa. Trans. Geol. Soc. S. Afr. 41:113-170.

Falconer, J. D. 1911. The geology and geography of northern Nigeria. London, Macmillan, 295 p.

Firman, J. B. 1983. Silcrete near Chundie Swamps: the stratigraphic setting. Geol. Surv. S. Aust. Q. Geol. Notes 85:2-5.

Frakes, L. A., coord. 1988. Australian Cretaceous shore- lines, stage by stage. Palaeogeogr. Palaeoclim. Palaeoecol. 59:31-48.

Frakes, L. A., and Bolton, B. R. 1984. Origin of manganese giants: sealevel change and anoxic-oxic history. Geology 12:83-86.

Glaessner, M. F., and Wade, M. 1958. The St. Vincent Basin. In Glaessner, M. F., and Parkin, L. W., eds. Geology of South Australia. Melbourne, Melbourne University Press, p. 115-126.

Gordon, F. R., and Lewis, J. D. 1980. The Meckering and Callingiri earthquakes, October 1968 and March 1970. Geol. Surv. W. Aust. Bull. 126. 229 p.

Hack, J. T. 1960. Interpretation of erosional topography in humid temperate regions. Am. J. Sci. 238A:80-97.

Harper, D. A.; Longstaffe, F. J.; Wadleigh, M. A.; and McNutt, R. H. 1995. Secondary K-feldspar at the Precambrian-Paleozoic unconformity, southwestern Ontario. Can. J. Earth Sci. 32:1432-1450.

Hassenfratz, J.-H. 1791. Sur l'arrangement de plusieurs gros blocs de différentes pierres que l'on observe dans les montagnes. Ann. Chim. 11:95-107.

Hill, S. M. 1999. Mesozoic regolith and palaeolandscape features in southeastern Australia: significance of interpretations of denudation and highland evolution. Aust. J. Earth Sci. 46:217-232.

Hills, E. S. 1934. Some fundamental concepts in Victorian physiography. Proc. R. Soc. Vic. 47:158-174.

1975. Physiography of Victoria. Melbourne, Whitcombe \& Tombs, $373 \mathrm{p}$.

Horton, R. E. 1945. Erosional development of streams and their drainage basins. Geol. Soc. Am. Bull. 56: 275-370.

Hossfeld, P. S. 1926. The geology of portions of the counties of Light, Eyre, Sturt and Adelaide. Unpub. M.S. thesis, University of Adelaide, $100 \mathrm{p}$.

Hutton, J. 1788. Theory of the Earth; or an investigation of the laws observable in the composition, dissolution and restoration of land upon the globe. Trans. R. Soc. Edinb. 1:209-304.

Jack, R. L. 1931. Report on the geology of the region to the north and north-west of Tarcoola. Geol. Surv. S. Aust. Bull. 15, 31 p.

Johnson, W. 1961. Exploration for coal, Springfield Basin, in the Hundred of Cudla-Mudla, Gordon-Cradock district. Geol. Surv. S. Aust. Rep. Invest. 16, 62 p.

Jones, O. T. 1931. Some episodes in the geological history of the Bristol Channel region. In Rep. Brit. Assoc. Adv. Sci., 98th meeting (Bristol, 1930), p. 57-82.

Judson, S., and Ritter, D. F. 1964. Rates of regional denudation in the United States. J. Geophys. Res. 69: 3395-3401.

Jutson, J. T. 1914. An outline of the physiographical geology (physiography) of Western Australia. Geol. Surv. W. Aust. Bull. 61, 240 p.

King, H. 1989. The rocks speak. Parkville, Victoria, Aust. Inst. Mining Metall., 306 p.

King, L. C. 1942. South African scenery. Edinburgh, Oliver \& Boyd, 308 p. . 1950. A study of the world's plainlands. Q. J. Geol. Soc. Lond. 106:101-131. 
1953. Canons of landscape evolution. Geol. Soc. Am. Bull. 64:721-752.

Knopf, E. B. 1924. Correlation of residual erosion surfaces in the eastern Appalachians. Geol. Soc. Am. Bull. 35: 633-668.

Kwitco, G. 1995. Triassic intermontane basins. In Drexel, J. F., and Preiss, W. V., eds. The geology of South Australia. Vol. 2. The Phanerozoic. S. Aust. Geol. Surv. Bull. 54:98-101.

Lidmar-Bergström, K. 1989. Exhumed Cretaceous landforms in south Sweden. Z. Geomorph. 72:21-40.

Linton, D. L. 1957. The everlasting hills. Adv. Sci. 14: 58-67.

Mabbutt, J. A. 1961. "Basal surface" or "weathering front." Proc. Geol. Assoc. Lond. 72:357-358.

- 1966. Landforms of the western MacDonnell Ranges. In Dury, G. H., ed. Essays in geomorphology. London, Heinemann, p. 83-119.

Maignien, R. 1966. Review of research on laterites. Natural Resources Research vol. 4. Paris, UNESCO, 148 p.

Miles, K. R. 1952. Geology and underground water resources of the Adelaide Plains area. Geol. Surv. S. Aust. Bull. 27, 257 p.

Molina Ballesteros, E.; Campbell, E. M.; Bourne, J. A.; and Twidale, C. R. 1995. Character and interpretation of the regolith exposed at Point Drummond, west coast of Eyre Peninsula, South Australia. Trans. R. Soc. S. Aust. 119:83-88.

Namier, L. B. 1955. Personalities and powers. London, Hamish Hamilton, 157 p.

Needham, R. S. 1982. East Alligator, Northern Territory. Bur. Miner. Resour. Geol. Geophys. Geol. Map Comm., scale 1 : 100,000. 27 p.

Parkin, L. W. 1953. The Leigh Creek coalfield. Geol. Surv. S. Aust. Bull. 31, 74 p.

Poag, C. W., and Sevon, W. D. 1989. A record of Appalachian denudation in postdrift Mesozoic and Cenozoic sedimentary deposits of the U.S. Middle Atlantic continental margin. In Gardner, T. W., and Sevon, W. D., eds. Appalachian geomorphology. Geomorphology 2:119-157.

Powell, J. W. 1875. Exploration of the Colorado River of the West and its tributaries. (1869-72). Washington, D.C., Government Printing Office, 291 p.

Reyment, R. A. 1989. Review of the major transgressions of the Cretaceous exemplified by the Tethys and South Atlantic. In LeMaitre, W., ed. Pathways in geology: essays in honour of Edwin Sherbon Hills. Hills Memorial Volume Committee. Melbourne, Blackwell, p. 220-229.

Rütimeyer, L. 1769. Ueber Thal- und See-Bilding. Beitrage zum Verstandniss der Oberfläche de Schweiz. Basel, Schultze, 95 p.

Schmidt, P. W.; Currey, D. T.; and Ollier, C. D. 1976. Sub-basaltic weathering, damsites, palaeomagnetism and the age of lateritization. J. Geol. Soc. Aust. 23: 367-370.

Sharp, R. P. 1940. Ep-Archean and Ep-Algonkian erosion surfaces, Grand Canyon, Arizona. Geol. Soc. Am. Bull. 51:1235-1270.

Skwarko, S. K. 1966. Cretaceous stratigraphy and palaeontology of the Northern Territory. Bur. Miner. Resour. Geol. Geophys. Bull. 73, 133 p.

Smart, J.; Ingram, J. A.; Doutch, H. F.; and Grimes, K. G. 1971. Recent mapping in the Carpentaria Basin: new stratigraphic names. Queensl. Gov. Min. J. 72: 227-233.

Sprigg, R. C. 1963. Geology and petroleum prospects of the Simpson Desert. Trans. R. Soc. S. Aust. 86:35-65.

Strahan, A., and Cantrill, T. C. 1904. The geology of the South Wales coal-field. VI. The country around Bridgend. Mem. Geol. Surv. Eng. Wales, 120 p.

Sutton, S. J., and Maynard, J. B. 1996. Basement unconformity control on alteration, St. Francois Mountains, S.E. Missouri. J. Geol. 104:55-70.

Taylor, G.; Eggleton, R. A.; Holzhauer, C. C.; Maconachie, L. A.; Gordon, M.; Brown, M. C.; and McQueen, K. G. 1992. Cool climate lateritic and bauxitic weathering. J. Geol. 100:669-677.

Taylor, G.; Taylor, G. R.; Binks, M.; Foudoulis, C.; Gordon, I.; Hestrom, J.; Minello, J.; and Whippy, F. 1985. Pre-basaltic topography of the northern Monaro and its implications. Aust. J. Earth Sci. 32:65-71.

Thornbury, W. D. 1954. Principles of geomorphology. New York, Wiley, 618 p.

Thwaites, F. T. 1931. Buried Precambrian of Wisconsin. Geol. Soc. Am. Bull. 42:719-750.

Tilley, C. E. 1921. A tholeiitic basalt from eastern Kangaroo Island. Trans. R. Soc. S. Aust. 45:276-277.

Twidale, C. R. 1956. Chronology of denudation in northwest Queensland, Australia. Geol. Soc. Am. Bull. 67: 867-882.

-1976. On the survival of paleoforms. Am. J. Sci. 276:77-95.

. 1982. Les inselbergs a gradins et leurs signification: l'exemple de 1'Australie. Ann. Geogr. 91: 657-678.

- 1984. The enigma of the Tindal Plain, Northern Territory. Trans. R. Soc. S. Aust. 108:95-103.

- 1985. Old land surfaces and their implications for models of landscape evolution. Rev. Geomorph. Dyn. 34:131-147.

- 1987. Etch and intracutaneous landforms and their implications. Aust. J. Earth Sci. 34:367-386.

- 1990. The origin and implications of some erosional landforms. J. Geol. 98:343-364.

- 1991. A model of landscape evolution involving increased and increasing relief amplitude. Z. Geomorph. 35:85-109.

- 1994. Gondwanan (Late Jurassic and Cretaceous) palaeosurfaces of the Australian craton. Palaeogeogr. Palaeoclim. Palaeoecol. 112:157-186.

. 1999a. Landforms ancient and recent: the paradox. Geogr. Ann. 81A:431-441.

1999b. Oldlands and the Australian Craton. Phys. Geogr. 20:273-304.

Twidale, C. R., and Bourne, J. A. 1975. Episodic exposure of inselbergs. Geol. Soc. Am. Bull. 86:1473-1481. 
1996. Development of the land surface. In Davies, M.; Twidale, C. R.; and Tyler, M. J., eds. Natural history of the Flinders Ranges. Adelaide, R. Soc. S. Aust., p. 46-62.

- 1998. Origin and age of bornhardts, southwest Western Australia. Aust. J. Earth Sci. 45:903-914.

. 2000a. A note on the role of protection in landform development: examples from granitic terrains. Z. Geomorph. In press.

—. 2000b. Rock bursts and associated neotectonic forms at Minnipa Hill, northwestern Eyre Peninsula, South Australia. Env. Eng. Geol. In press.

Twidale, C. R.; Horwitz, R. C.; and Campbell, E. M. 1985. Hamersley landscapes of the northwest of Western Australia. Rev. Geol. Dyn. Geogr. Phys. 26:173-186.

Twidale, C. R., and Vidal Romani, J. R. 1994. The Pangaean inheritance. Cuad. Lab. Xeol. Laxe 19:7-36.

Van Hise, C. R. 1896. A central Wisconsin baselevel. Science 4:57-59.

Watts, W. W. 1903. Charnwood Forest, a buried Triassic landscape. Geogr. J. 21:623-633.

Wayland, E. J. 1934. Peneplains and some erosional landforms. Geol. Surv. Uganda, Ann. Rep. Bull. 1:77-79.

Weidman, S. 1903. The pre-Potsdam peneplain of the preCambrian of north-central Wisconsin. J. Geol. 11: 289-313.

Wellman, P. W. 1971. The age and palaeomagnetism of the Australian Cainozoic volcanic rocks. Unpub. Ph.D. thesis, Australian National University, Canberra, $388 \mathrm{p}$.

Willis, B. 1936. East African plateaus and rift valleys: studies in comparative seismology. Carnegie Inst. Wash. Publ. 470, 358 p.

Woodard, G. D. 1955. The stratigraphic succession in the vicinity of Mount Babbage Station, South Australia. Trans. R. Soc. S. Aust. 78:8-17.

Woodburne, M. O. 1967. The Alcoota fauna, central Australia. Bur. Miner. Resour. Geol. Geophys. Bull. 87, $187 \mathrm{p}$.

Wooldridge, S. W. 1951. The role and relations of geomorphology. In Stamp, L. D., and Wooldridge, S. W., eds. London essays in geography (Llewellyn Rodwell Jones Memorial Volume). London, Longmans Green, p. 19-31.

Wopfner, H. 1960. On some structural developments in the central part of the Great Australian Artesian Basin. Trans. R. Soc. S. Aust. 83:179-194.

. 1968. Cretaceous sediments on the Mt. Margaret Plateau and evidence for Neo-tectonism. Q. Geol. Notes Geol. Surv. S. Aust. 28:7-11.

1969. Mesozoic era. In Parkin, L. W., ed. Handbook of South Australian geology. Adelaide, Geol. Surv. S. Aust., p. 133-171.

Young, R. W. 1977. Landscape evolution in the Shoalhaven River catchment of southeastern New South Wales. Z. Geomorph. 21:262-283.

. 1983. The tempo of geomorphological change: evidence from southeastern Australia. J. Geol. 91: 221-230.

Young, R. W., and McDougall, I. 1993. Long-term landscape evolution: early Miocene and modern rivers in southern New South Wales. J. Geol. 101:35-49.

Young, R. W.; Short, S. A.; Price, D. M.; Bryant, E. A.; Nanson, G. C.; Gardiner, B. H.; and Wray, R. A. L. 1994. Ferruginous weathering under cool temperate climates during the Late Pleistocene in southeastern Australia. Z. Geomorph. 38:45-57. 